\title{
Understanding non-attendance in outpatient paediatric clinics
}

\author{
R Andrews, J D Morgan, D P Addy, A S McNeish
}

\begin{abstract}
Outpatient clinic appointments are often not kept. There has been little study of the reasons for this, but failure to attend may affect future health. Our study was based on the children's outpatient department of a large inner city district general hospital. The parents of 34 children who had failed to keep appointments and of 12 who did attend were interviewed in depth and the appointment systems of the hospital and of a nearby regional referral centre for children were reviewed.

At the district general hospital $23 \%$ of first appointments and $35 \%$ of subsequent appointments were not kept. We found that parents usually made a conscious decision about attending, balancing the perceived advantages and disadvantages of doing so. Their assessment of the severity of the child's illness was crucial in this. Twenty one of the $\mathbf{3 4}$ children who had not attended were assessed at the time of interview as still needing to attend. Of these, 16 subsequently kept an appointment and 11 underwent further investigation or treatment. We conclude that children who are not brought for outpatient appointments may be at risk of avoidable ill health and that ways of either ensuring attendance at outpatient clinics or providing alternative means of health supervision are needed.
\end{abstract}

Failure to keep outpatient appointments is common. ${ }^{1-3}$ It wastes health service resources, disrupts clinic appointment systems, and may affect the patients' health. The reasons for failing to attend are not well understood. We therefore studied parents and children in a paediatric outpatient clinic to find out why parents did not bring children for appointments and whether the failure to do so might affect the children's health.

Non-compliance with medical advice has been much studied, ${ }^{3-7}$ but much less has been written about failure to keep appointments, which is a specific form of non-compliance. Previous work on non-attendance has concentrated on measuring the scale of the problem or on comparing characteristics of those who attend and those who do not. ${ }^{8}$ We decided to carry out in depth interviews with parents in order to understand why some do not attend. We also studied patterns of non-attendance in several outpatient clinics, including both general paediatric and subspecialty clinics, and assessed the health of children who had not been brought for appointments.

\section{Methods}

Between September 1985 and October 1986 the appointment lists and related medical records of two general paediatric clinics in a large inner city district general hospital (Dudley Road Hospital, Birmingham) were examined by one of us (RA). In 1987 a similar study was carried out in six paediatric specialty clinics at the Birmingham Children's Hospital. The purpose of these studies was to assess patterns of nonattendance in the different clinics. The service setting for the process of referral, appointment, consultation, and discharge was also assessed. This involved identifying referral routes, administrative arrangements for making appointments and procedure after failure to attend, the role of liaison health visitors, and the ways in which the clinics were organised. For this purpose interviews were held with administrative, clerical, medical, and nursing staff at the hospitals and with liaison health visitors. Eleven general practitioners were also interviewed. These results will be reported in a later paper.

The major part of the study involved in depth, semistructured interviews with one or both of the parents of a sample of 48 children who had been given appointments to attend a general paediatric clinic at Dudley Road Hospital. Interviews lasted between 35 minutes and 2 hours 5 minutes (average 1 hour 10 minutes) and all were recorded and transcribed for later analysis. All but two (who could not be traced) were seen at their home by the field worker (RA).

Children were selected prospectively from clinic appointment lists beginning in December 1986 and the sample was divided into the quotas specified in table 1 . Selection continued until the last quota category was filled. While this was not a random sample we have no reason to suspect the introduction of a systematic bias. Distinction was drawn between appointments for a first consultation in an outpatient clinic (primary appointments) and those for subsequent consultations (secondary appointments).

The methods used for interviewing and for analysing interview transcripts (the 'qualitative method') were based on techniques described by Ritchie and Sykes, ${ }^{9}$ and RA received training in the techniques before the interview programme began. The main topics covered during the interviews were parents' perception of their child's health and symptoms, parents' account of their hospital experience, the decision about attendance, and certain characteristics of the respondents. The approach sought the respondent's own account of events and experiences 
Table 1 Selection criteria and sample quotas

\begin{tabular}{|c|c|c|c|c|}
\hline & \multicolumn{3}{|c|}{ Children who did not attend } & \multirow[t]{3}{*}{ Children who attended 5} \\
\hline & \multicolumn{2}{|c|}{ First appointments } & \multirow[t]{2}{*}{ Subsequent appointmentsf } & \\
\hline & $\begin{array}{l}A^{*} \\
(\text { After admission })\end{array}$ & $\begin{array}{l}\text { Bt } \\
\text { (Referral } \\
\text { from general practitioner) }\end{array}$ & & \\
\hline $\begin{array}{l}\text { Dr Y } \\
\text { Dr Z }\end{array}$ & $\begin{array}{l}6 \\
6\end{array}$ & $\begin{array}{l}6 \\
6\end{array}$ & $\begin{array}{l}6 \\
6\end{array}$ & $\begin{array}{l}6 \\
6\end{array}$ \\
\hline
\end{tabular}

*Admitted as an emergency but failed to attend two primary outpatient appointments.

tReferred but on no occasion attended.

FFour consecutive appointments given within 12 months. Attended first then failed to attend for two or more.

SAttended each consecutive appointment within a 12 month period.

Table 2 Gross non-attendance rates at eight paediatric outpatient clinics

\begin{tabular}{|c|c|c|c|c|}
\hline \multirow[t]{2}{*}{ Clinic } & \multicolumn{2}{|c|}{$\begin{array}{l}\text { Appointments for first consultation } \\
\text { (primary appointments) }\end{array}$} & \multicolumn{2}{|c|}{$\begin{array}{l}\text { Appointments for subsequent consultation } \\
\text { (secondary appointment) }\end{array}$} \\
\hline & No given & No (\%) failed to attend & No given & No (\%) failed to attend \\
\hline $\begin{array}{l}\text { General paediatric: } \\
\text { A } \\
\text { B } \\
\text { C } \\
\text { General surgical paediatrics } \\
\text { Orthopaedic } \\
\text { Diabetic } \\
\text { Cardiology } \\
\text { Oncology }\end{array}$ & $\begin{array}{r}529 \\
254 \\
317 \\
391 \\
405 \\
15 \\
222 \\
32\end{array}$ & $\begin{array}{r}120(23) \\
59(23) \\
87(27) \\
149(38) \\
131(32) \\
2(13) \\
13(6) \\
2(6)\end{array}$ & $\begin{array}{r}3131 \\
1025 \\
1660 \\
1223 \\
842 \\
1098 \\
581 \\
2342\end{array}$ & $\begin{array}{r}1119(36) \\
348(34) \\
558(34) \\
267(22) \\
415(49) \\
225(21) \\
100(17) \\
313(13)\end{array}$ \\
\hline
\end{tabular}

and transcripts of these accounts were later analysed. Data obtained in this way were related to our own observations of the way the clinics were organised and to information contained in the hospital records. At the time of the interview, an assessment of the child's health was made according to a profile agreed by the research team and this assessment was reviewed with a consultant paediatrician (DPA) with the hospital notes if the child had been seen in hospital.

\section{Results}

PATTERNS OF NON-ATTENDANCE

The gross non-attendance rates for the eight clinics studied are given in table 2 . Attendance rates were higher in specialist clinics where many of the children might be expected to have serious or life threatening conditions. In seven of the eight clinics primary appointments were less likely to be missed than secondary. It should be noted that the gross non-attendance rates are based on appointments and not on children. Table 3 shows that the two general paediatric clinics at Dudley Road Hospital each had a gross non-attendance rate for primary appointments of about $23 \%$, but in both clinics only about $8 \%$ of children failed to attend two consecutive primary appointments. The gross non-attendance rates for secondary appointments were $36 \%$ in clinic $A$ and $34 \%$ in clinic B. In these clinics children were almost always removed from the appointments list after two consecutive missed appointments but from a total of 1118 missed secondary appointments, only 171 children were removed. This suggests that a substantial number of parents may be missing every second or third appointment ('playing the system').
PARENTS' DECISION NOT TO ATTEND

Table 4 summarises the main reasons for not attending, though in depth interviews revealed that the decision not to attend was usually a conscious and complex one influenced by many factors. Parents balanced the benefits of attending against the costs, and their perception of the severity of the symptoms and of their child's prognosis was crucial in this. For example, if the child's symptoms had subsided and the costs of attending were substantial (such as arranging child care for other children, taking time off work, or travel costs for very low income families) parents were less likely to

Table 3 Attendance patterns at two clinics

\begin{tabular}{|c|c|c|}
\hline & Clinic $A$ & $\overline{\text { Clinic B }}$ \\
\hline $\begin{array}{l}\text { Total children in cohort } \\
\text { No }(\%) \text { who attended first appointment }\end{array}$ & $\begin{array}{l}444 \\
359(81)\end{array}$ & $\begin{array}{l}254 \\
204(80)\end{array}$ \\
\hline $\begin{array}{l}\text { No }(\%) \text { who missed first, attended } \\
\text { second appointment } \\
\text { No }(\%) \text { who failed to attend first and }\end{array}$ & 50 (11) & $29(11)$ \\
\hline $\begin{array}{l}\text { second appointments } \\
\text { Gross non-attendance rate }(\%)^{*}\end{array}$ & $\begin{array}{l}35(8) \\
(22 \cdot 7)\end{array}$ & $\begin{array}{l}21(8) \\
(23 \cdot 3)\end{array}$ \\
\hline
\end{tabular}

*Number of failed appointments divided by number of appointments offered $\times 100$.

Table 4 Children who did not attend: principal reason for not attending

\begin{tabular}{lc}
\hline & No of cases \\
\hline Child well, decided not to attend & 11 \\
Forgot appointment & 10 \\
Mother ill & 3 \\
Domestic problems or other contingencies & 8 \\
Administrative error & 1 \\
Sought private care & 1 \\
Not traced by interviewer & 2 \\
\hline Total non-attenders & 36 \\
\hline
\end{tabular}


attend. Parents claimed that the reasons for the appointment had not always been made clear to them either by the general practitioner in the case of primary appointments or by the hospital doctor in the case of secondary appointments. Some parents disagreed with their general practitioner about the need for hospital referral.

Eleven children did not attend because their parents decided they were now well and no longer needed to attend. Of these, only two were being referred for a primary appointment by their general practitioner. The rest had already attended hospital, either as inpatients $(n=6)$ or outpatients $(n=3)$. It is noticeable that the diagnoses given in table 5 support the impression given by the attendance figures for speciality clinics (table 2) that attendance is likely to be better when the condition is perceived as being more serious; a not unexpected finding. Parents' experience at previous clinic visits could, of course, influence their decision about further attendance. An unsatisfactory experience at any point in the visit (reception, waiting, or consultation) could discourage future attendance and might explain why non-attendance for secondary appointments is much more common than for primary appointments.

For three children their parents' fear of the consequences of attending the clinic appeared to be an important factor. In two cases this was a fear of being told that their child had a handicapping condition and one mother's previous contact with a police officer in the casualty department had led her to fear being wrongly accused of child abuse.

Some parents had simply forgotten the

Table 5 Diagnoses of children in sample. Parents' decision to attend or not attend

\begin{tabular}{|c|c|}
\hline \multicolumn{2}{|c|}{ Children who did not attend $(n=36)$} \\
\hline $\begin{array}{l}\text { Diarrhoea } \\
\text { Constipation } \\
\text { Failure to thrive }(n=5) \\
\text { Rectal pain and bleeding } \\
\text { Abdominal pain } \\
\text { Pigmentation of skin } \\
\text { In-toeing }(n=2) \\
\text { Stiff legs, odd gait } \\
\text { Febrile convulsions }(n=9) \\
\text { Febrile convulsion: renal } \\
\text { anomaly }\end{array}$ & $\begin{array}{l}\text { Febrile convulsion, idiopathic } \\
\text { precocious menarche } \\
\text { Delayed development }(n=2) \\
\text { Systolic murmur } \\
\text { Otitis media } \\
\text { Asthma }(n=3) \\
\text { Chest infection } \\
\text { Dysuria } \\
\text { Bow tibia } \\
\text { Rickets, eczema } \\
\text { Bronchiolitis, eczema }\end{array}$ \\
\hline \multicolumn{2}{|c|}{ Children who attended $(n=12)$} \\
\hline $\begin{array}{l}\text { Apnoea, eczema oesophageal } \\
\text { reflux } \\
\text { Duplex kidney collecting } \\
\text { system } \\
\text { Haematemesis, anaemia } \\
\text { Eczema, asthma } \\
\text { Asthma } \\
\text { Haemolytic uraemic syndrome }\end{array}$ & $\begin{array}{l}\text { Asthma, eczema } \\
\text { Blind, convulsions } \\
\text { Microcephaly, cerebral palsy } \\
\text { Microcephaly } \\
\text { Epilepsy } \\
\text { Chronic diarrhoea }\end{array}$ \\
\hline
\end{tabular}

appointment. This was more likely to happen when the disappearance of symptoms was no longer a daily reminder or when the time between notification of the appointment and the date of the appointment was long (more than six months for some children). A small number of failed appointments resulted from administrative errors or from children having changed address.

HEALTH OF CHILDREN WHO DID NOT ATTEND Thirty four of the 36 children who did not attend (table 1) were assessed at the time of the in depth interview with their parents. The results of this assessment were then reviewed with the consultant, together with their hospital records, and 21 were assessed as needing further medical attention (table 6). It is worth noting that almost half (11 of 24) of those who had previously been seen in hospital were thought to no longer need to attend. After the interview, the parents of 17 children asked for another outpatient appointment and 16 subsequently attended. Eleven of these were either given further appointments or referred to a consultant in a different specialty, in all cases for further investigation or treatment.

\section{Discussion}

It is important to recognise that much of our work is based on a small sample of parents and children using two outpatient clinics. Our conclusions are offered, not as definitive statements, but more as propositions that will require further investigation. On the other hand, we believe the study has substantially contributed to our understanding of the phenomenon and consequences of non-attendance. It provides clinicians and managers alike with a more useful framework for examining their own services.

Three major conclusions can be drawn from the study. First, our findings confirm that nonattendance is a significant problem, both numerically, and in terms of hazard to children's health. The case for finding ways to reduce non-attendance or to provide alternative means of health supervision is therefore strong.

Second, the reasons for non-attendance are not straightforward, at least in the case of children. For parents, the decision to attend or not can often be a complex one, which is importantly affected by their perception of their child's health and symptoms. They will balance the costs of attending with the perceived benefits of attending. The comments of general

Table 6 Health outcomes of the children who did not attend

\begin{tabular}{|c|c|c|c|c|}
\hline & \multicolumn{2}{|l|}{ First appointments } & \multirow{2}{*}{$\begin{array}{l}\text { Subsequent } \\
\text { appointments }\end{array}$} & \multirow[t]{2}{*}{$\overline{\text { Total }}$} \\
\hline & $\begin{array}{l}\text { Referral from } \\
\text { general practitioner }\end{array}$ & After admission & & \\
\hline $\begin{array}{l}\text { Needed further hospital outpatient treatment } \\
\text { Needed further hospital diagnostic tests } \\
\text { Needed tests or treatment by general practitioner } \\
\text { No signs or symptoms of ill health }\end{array}$ & $\begin{array}{l}3 \\
5 \\
0 \\
2\end{array}$ & $\begin{array}{l}3 \\
3 \\
2 \\
4\end{array}$ & $\begin{array}{l}5 \\
0 \\
0 \\
7\end{array}$ & $\begin{array}{r}11 \\
8 \\
2 \\
13\end{array}$ \\
\hline Total & 10 & 12 & 12 & 34 \\
\hline
\end{tabular}


practitioners and parents suggest that the case made by Marinker et al for improving primary referral practice could also be extended to follow up appointment practice. ${ }^{10}$ Hospital medical staff, referring general practitioners, and potentially nurses and health visitors, all have an important role in helping parents to make the most informed decision given their circumstances. ${ }^{11}$

Third, the means for effective follow up of non-attenders merits further investigation. Although there are steps that could reduce nonattendance, it seems unlikely ever to be eliminated. Our evidence suggests that a substantial proportion (if not a majority) of children who do not attend can be expected to have health problems warranting further medical attention. Most of these children had already been removed from the appointment list and their general practitioner notified, but unless particular concern was expressed by a consultant, the children's general practitioner did not routinely follow them up. In the absence of our interview, the children in the study would have had no contact with health professionals until their symptoms worsened to the point where their parents would have sought medical advice. It is interesting that after the in depth interview, further outpatient appointments were requested and kept by the parents of 16 children. This suggests that follow up by a health professional (such as an appropriately trained health visitor), using a counselling approach, can be effective. Even if a child appears to have recovered, it is important that this is confirmed (preferably by the child seeing the referring general practitioner) and that the hospital is notified to prevent further appointments being made and broken.

We thank all the parents who participated in this study and the outpatient staff and medical record officers of both hospitals. We are indebeted to Helen Finch and colleagues at Social and Community Planning Research, London, for their advice. Ruth Andrews was supported by Birmingham Inner-City Partnership and Birmingham Children's Hospital Centenary Fund.

1 Jones DT. A survey of hospital outpatient referral rates, Wales, 1985. Br Med f 1987;295:734-6.

2 Anderson FP, Rowe DS, Dean VC, Arbisser A. An approach to the problem of non-compliance in a paediatric outpatient clinic. Am $\mathcal{F}$ Dis Child 1971;122:142-3.

3 McGlade KJ, Bradley T, Murphy GJJ, Lundy GPP Referrals to hospital by general practitioners: a study of Referrals to hospital by general practitioners: a study of
compliance and communication. $\mathrm{Br} M e d \mathcal{f} 1988 ; 297$ : 1246-8.

4 McMahon T, Clarke CM, Bailie GR. Who provides patients with drug information? Br Med f 1987;294:355-6.

5 Robinson J. An evaluation of health visiting. London: Council for the Education and Training of Health Visitors, 1983.

6 Pill R, French J, Harding K, Scott N. Invitation to attend health check in a general practice setting: comparison of attenders and non-attenders. $\mathcal{F} R$ Coll Gen Pract 1988;38: 53-6.

7 Cockburn J, Gibberd RW, Reid AL, Sanson-Fisher RW. Determinants of non-compliance with short-term antibiotic regimens. $\mathrm{Br}$ Med $\mathcal{F}$ 1987;295:814-8.

8 Cooper N, Lynch M. Lost to follow-up. Arch Dis Child 1979; 55:765-9.

9 Ritchie J, Sykes W. Advanced workshop in applied qualitative research. London: Social and Community Planning Research Publications, 1986

10 Marinker M, Wilkin D, Metcalfe DH. Referral to hospital: can we do better? Br Med $\mathcal{F}$ 1988;297:461-4.

11 Grace JF, Armstrong D. Reasons for referral to hospital: extent of agreement between the perceptions of patients, general practitioners and consultants. Fam Pract 1986;3: 143-7. 